\title{
The Prospect of the Digitization of Agricultural Enterprises in Terms of Ensuring their Competitiveness for Management Purposes
}

\author{
T. Ostapchuk, H. Kupalova, Y. Hudzynska, L. Butsenko
}

\begin{abstract}
Ensuring business competitiveness is a key challenge for companies in a dynamic open market. And it is the specificity of modern business conditions that creates stringent requirements for business organization in particular for domestic agricultural enterprises. High degree of riskiness of activity, deep standardization of production of the industry in Ukraine and on the international market, as well as limited resources, high consumer requirements for environmental friendliness of production and safety of the final product are the key factors driving the search for new directions of formation of competitive advantages of agricultural enterprises today. One of them is digitization - the process of digitization and automation of production and economic operations in order to increase their efficiency in economic, social and environmental aspects. The article is devoted to substantiating the prospect of economization digitization in the process of ensuring the competitiveness of agricultural enterprises and the formation of a mechanism for implementation of the digitization criterion in the system of management evaluation of enterprise competitiveness.
\end{abstract}

Key words: digitization, management, social responsibility

\section{INTRODUCTION}

Another trendy term has entered daily life and is gaining momentum and popularity in the field of business. Digitization is a logical continuation of the automation of production processes in business and the global process of digitization of information.Digital technologies for business contribute to the formation of competitive advantages by improving the processes of gathering and analyzing information and help making effective management decisions.A wide range of technologies - from interactive databases to automatic multitasking mechanisms allows to increase the efficiency of both individual production processes and the activity of the enterprise as a whole. However, in addition to the positive qualities, the dynamic development of digitization processes can also have a destructive effect, increasing the requirements for business processes organization and shifting

Revised Version Manuscript Received on October 15, 2019.

T. Ostapchuk, Department of Management and Enterpreneurship of Zhytomyr Polytechnic State University, Zhytomyr, Ukraine. (Email: ostapchuk-a@ukr.net)

H. Kupalova, Doctor of Economic Sciences, Professor of theDepartment of Environmental Management and Entrepreneurship at Taras Shevchenko National University of Kyiv, Kyiv, Ukraine (Email: prof.galina@gmail.com)

Y. Hudzynska, Department of management named after prof. Y. S. Zavadskyi, National university of life and environmental sciences of Ukraine, Kyiv, Ukraine. (Email: lunareclipse@ukr.net)

L. Butsenko, Department of management named after prof. Y. S. Zavadskyi, National university of life and environmental sciences of Ukraine, Kyiv, Ukraine. (Email: 1-bucenko@ukr.net) competition from the plane of consumer demand to the level of efficient organization of economic processes. As a result, the problem of social responsibility of producers can be aggravated - both in the relationship with the consumer and inrelation to his own team, because in the pursuit of efficiency, the risk of human indulgence in favor of technology is increased.

Thus, the problem of rational implementation of digitization in the system of ensuring the competitiveness of the enterprise is actualized.

This applies in particular to domestic agricultural enterprises, where traditionally the overwhelming majority of employees, including managers, do not have higher professional education, and because of the mentality it is difficult to adapt to change.

Digitization is understood to mean deep transformation, the penetration of digital technologies to optimize and automate business processes, increase productivity, and improve communication with consumers.

World experience in the use of digitization processes in agricultural production covers the following areas:

- analytical platform - interactive databases for farm management (agricircle.de, 365farmnet.com, agrar-info. Com, app.ackerchef.de, agriport.net, agro-sat.de, nextfarming.de, bac.myyara.com ). For example, German experience shows that $50 \%$ of farms use software with a field management feature that allows to manage a land bank, simplifying complex relationships (including rents) in this area.

- precision farming technologies - sensory means of monitoring the physico-chemical status of plants and soil, which allow for rapid adjustment of agronomic activities, reducing the risk of over-spending of resources and finances.

- marketing platforms - facilitating communication with consumers and contractors by presenting comprehensive product information and terms of engagement [1].

\section{METHODOLOGY}

The methodological aspect of determining the utility of digitization in order to increase the competitiveness of an enterprise can be presented on the basis of the classical approach to assessing the competitiveness of an enterprise, namely the polygon of competitiveness. The basis is a list of criteria proposed [2], namely: the financial condition of the 
enterprise, production efficiency, sales efficiency, competitive potential of the enterprise, environmental friendliness, social efficiency, image of the enterprise, competitiveness of products. These criteria comprehensively cover the system of competitiveness formation, revealing it from the standpoint of socio-economic and environmental-economic responsibility.

The selected evaluation criteria are evidenced by their interconnectedness and balance in the overall evaluation of the resultant indicator - competitiveness. Thus, the efficiency of production is characterized as the level of providing the enterprise with production resources, the rationality of their use in the production process, as well as the quality of the organization - as a direct management activity for combining employees with means of labor.Indicators of this criterion can be selected:

- the growth rate of gross output,

-productivity,

- the rate of change of production costs,

- growth rates of production of production per unit area in crop production and head of livestock in animal husbandry, etc.

Sales efficiency is characterized by the quality of marketing activity of the enterprise - the degree of consideration of the needs of potential and actual consumers in the process of creating and selling products. To evaluate this sphere of activity of the enterprise is possible by:

- market share growth rate,

- the relative competitiveness of the enterprise to its main competitors in particular types of products,

- growth rate of prices for products.

Social efficiency is an actual criterion for effective activity in today's environment, given the generally accepted concept of sustainable development, in which the social, environmental and economic components are equal elements of preserving resources for future generations and fulfilling the needs of today. The social efficiency of the enterprise should be considered from the point of view of interaction with the society and own employees.Key indicators of enterprise social efficiency:

- the level of providing the society with jobs,

- the level of wages,

- staff turnover,

- participation of the company in charitable social projects and programs.

The aforementioned factor - the environmental friendliness of production - also characterizes the social consciousness of business and is a significant competitive advantage in the face of increasing regulatory requirements for doing business today in Ukraine and in the world. Assessment of environmental friendliness can be measured by:

- the rate of reduction of hazardous waste of production;

- the share of products produced by resource-saving technologies, etc.

Product competitiveness is the starting point for assessing the competitiveness of an enterprise, because it is through the products that companies present themselves on the market. In terms of methodology, this criterion can be easily disclosed through the coefficient of product competitiveness, which is formed on the basis of partial indicators characterizing the products in economic and consumer aspects according to the specifics of the product.

The above criteria directly influence the image of the company, forming a certain image in consumer perception and determining its place in the market. Thus, the indicators of this criterion can be:

- the market share of the company,

- type of market niche,

- export growth rate.

The competitive potential of an enterprise can be disclosed as a set of potential competitive advantages, based on the integrated competitive advantage index proposed by [3], which includes the coefficients (formula 1):

- - competitive advantages of products,

- - resource potential,

- - management profile,

- - control systems,

- - the effectiveness of implemented solutions

- - the market position of the enterprise,

- - communication and economic relations,

- - the institutional attractiveness of the enterprise,

- - innovative development,

- - environmental development,

- - social development.

$$
\text { ??? } ?
$$

where: ????a - integrated coefficient of competitive advantages; $P C_{1,11}$ - partial coefficients of competitive advantages.

At the same time, we believe that the financial condition of the company is one of the elements of the resource potential of the company, so it is not advisable to bring it into a separate factor of competitiveness. The polygon method of competitiveness regulates the existence of eight evaluation criteria.

Thus, the vacated position is proposed to take away the criterion of the level of digitization of production. The latter in the narrow sense can be described as the degree of automation and computerization of production and economic processes [9]. Indicators of the level of digitization of the enterprise may be, in particular, the following:

- the share of products produced on the basis of automated technologies in the total volume of production of the enterprise;

- the growth rate of the introduction of the latest digital technologies into the production process;

- the degree of electronic document flow of the enterprise;

- the average response time of the respondent in the process of internal communication of the company, etc.

The level of enterprise digitization can be determined by the formula (2):

$$
L D=\sqrt[m]{P F_{1} \ldots P F_{n}},
$$

where: LD - level of digitization of the enterprise; $P F_{1, n}-$ partial factors of digitization; $\mathrm{n}$ - number of factors, included into investigation. 
It should be noted that the list of indicators by which the enterprise's competitiveness criteria can be represented may vary according to: the focus of the assessment being carried out; information and time resources allocated for analysis; qualifications of the expert who conducts the analysis.

In turn, the integral indicator of the level of competitiveness of the enterprise based on the proposed evaluation criteria, taking into account the level of production digitization, can be represented by a similar formula (3):

where: $\mathrm{CC}$ - coefficient of competitiveness of the enterprise; $P F_{1,8}-$ partial factors of competitiveness: production efficiency, digitization level of the company, competitiveness of products, sales efficiency, competitive potential of the company, environmental friendliness of production, company image, social efficiency.

The proposed model of enterprise competitiveness assessment can be graphically represented as a polygon of competitiveness (Figure 1).

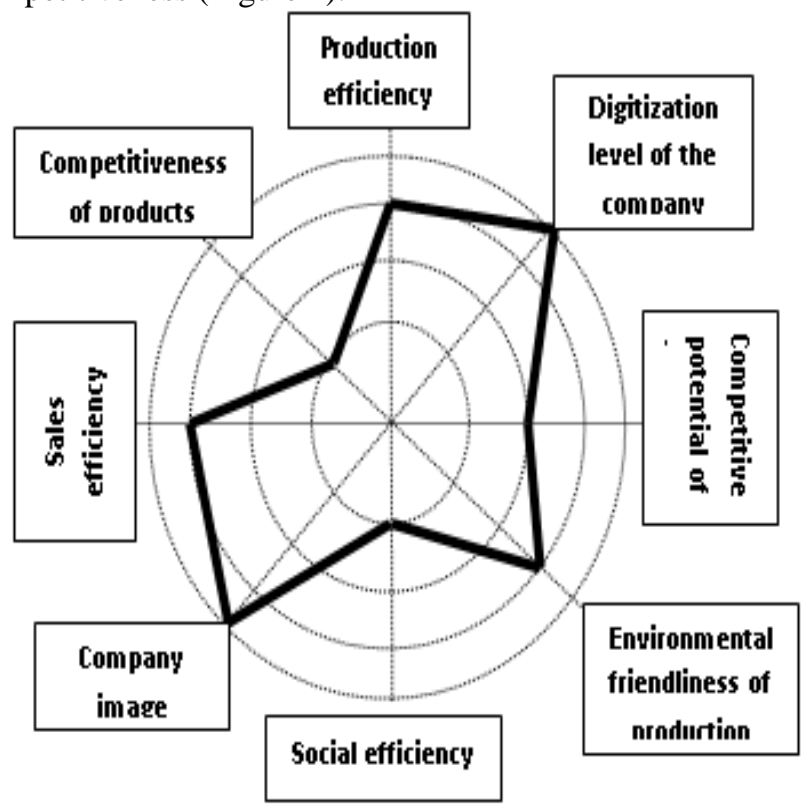

Fig. 1 Polygon of competitiveness

This model of competitiveness can also be used to predict performance in the form of correlation-regression dependence (formula 4):

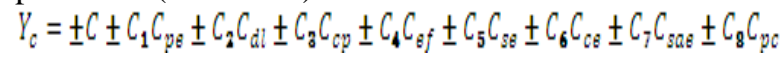

Where: $Y_{c}-$ level of the competitiveness of the enterprise; $\mathrm{C}$ - free member; $C_{1} \ldots C_{8}-$ coefficients of significance of factors;

\section{RESULT AND DISCUSSION}

The actual state of digitization of the agrarian sector of Ukraine can be characterized as dynamically developing not only due to borrowing of foreign technologies, but also due to the development of the domestic sphere of IT and the latest technologies.

In particular, Ukrainian startup Kray Technologies since 2017 is working on contracts for the production of agrodrons, which are already patented in the USA. The technology is equipped with a computer vision system that allows to identify and bypass obstacles. The productivity of the invention is $27-48$ hectares per hour with a record speed of $110 \mathrm{~km} / \mathrm{h}$.

A related technology for drones is cloud-based data collection and processing services. It is believed that the tandem "drone-cloud" began the full introduction of the latest technologies in the industry.Another example of digitization in the agrarian sector of Ukraine is the digital terrain maps that allow to optimize agrotechnical measures according to the specificity of the terrain and the condition of the soil. This reduces land costs and increases crop yields. In addition, technology allows:

- visualize the dynamics of soil analysis;

- analyze satellite images;

- create crop yield maps;

- identify the most productive areas;

- to track the dynamics of crop development;

- control the condition of the fields;

- predict the yield.

The Water Cloud UA project saves money on irrigation and provides watering for crops in areas with fresh water supply problems. The installation works on the basis of the conditioner on the basis of the solar battery, and therefore the technology is economical and consistent with the principles of sustainable development. This fact testifies to the benefit of this technology as a competitive advantage for agricultural enterprises.

In addition to crop-related technologies, agricultural technologies have a significant impact on technologies responsible for planning, managing business processes, selling products, and communicating with potential buyers through various channels, including CRM (Customer Relationship Management) and BPM (Business Process Management).Ukraine's widespread bpm'online platform, featuring customer relationship management and business process management tools, developed by Terrasoft, a Ukrainian company, allows scheduling and recording external meetings, demonstrating agricultural products to customers, and placing orders immediately.

An example of the use of the above mentioned systems is the leading agricultural holding of Eastern Europe "Mironovskyi Khliboproduct", whose land bank is about 370 thousand hectares. agricultural production, automation of production processes of database accumulation, structuring and analysis of information, satellite monitoring, the use of unmanned aerial vehicles.

The introduction of a comprehensive information system has helped reduce the burden on employees of land departments and use information about the land bank in other programs or applications.Thus, "Mironovskyi Khliboproduct" has created a single platform for collecting, storing and processing data on cultivated land with precise geopositioning [4].These positive changes, caused by digitization, increased production efficiency and ensured the company's competitiveness.

The example of "Mironovskyi Khliboproduct" is illustrative, but it should be noted that the latest digital technologies are difficult to access for small and 
economically weak agricultural enterprises because of significant initial financial investment. Other peculiarities of economic activity in the agricultural sphere of Ukraine, which have a direct impact on the development of the enterprises of the industry, in particular the process of digitization, should be taken into account.

An obstacle to mass adoption of technologies for precision farming in Ukraine is outdated data agrochemical of soil as the primary mapping source of information about ground cover materials are examination of soil early 60 s of the last century, and the quality of soil, which is the basis for monetary valuation of land, - in the 90s [5].

Improvement of these preconditions for digitalization is possible only under conditions of state regulation. In this context, the concept of development of the digital economy has been developed, which has received official approval in the form of Cabinet of Ministers of Ukraine Decree No. $67 \mathrm{R}$ of January 17, 2018 "On the Concept of Development of the Digital Economy and Society of Ukraine for 2018 - 2020" the first comprehensive step in the direction of development digital economy in Ukraine [6].

Despite the obvious usefulness of digital technology, people's willingness to move to new working conditions remains a significant issue. Particularly acute is the problem regarding the agricultural sector, where the majority of workers do not have adequate level of education.

In this context, much attention is paid within the Concept to the development of digital competencies.

The ability to use digital technology to work gradually becomes necessary for most majors and professions, that is a through or multiplatform.

In this context, the development of non-formal education providers - private organizations and online individual education services - is promising.With the support of state institutions, this area will be able to help quickly improve the skills of employees and management staff of agricultural enterprises. Creating favorable conditions and finding appropriate models of public-private partnerships with non-formal education operators, supporting their regional scaling will increase private investment in the field, the emergence of new operators and, in the short term, significantly increase the opportunities of citizens in cities and especially in rural areas, professions and more.

One of the important tasks is updating the national occupational classifier, developing and approving the list of digital professions based on the requirements of the labor market, digital trends, etc., with further development of the appropriate program of their introduction in specialized educational institutions.

Digital skills and competencies are the key to the full development of the digital economy. Digital literacy should be a core competency. Most Ukrainian citizens already enjoy the benefits of digital technology. The next step is to ensure that these benefits make Ukrainians as a whole and agricultural enterprises in particular economically successful.

The introduction of the digital workplace concept should be seen as the virtual equivalent of a physical workplace, which requires proper organization, use and management, as it should be the key to improving employee performance and creating better working conditions for them.

In terms of the digital economy jobs are no longer tied to a

physical location. They become "digital", virtual, mobile, that is, do not require a permanent employee in the workplace. The concept of "digital jobs" is spreading extremely fast in the business environment and is favorably received by the overwhelming majority of workers who like flexible working methods, the ability to work at home, on vacation, from anywhere.

The digital workplace promotes flexibility in the way civil servants perform their job responsibilities, encourages them to work together and interact, supports decentralized and mobile work environments, provides the choice of technology to work with. The benefits of digital workplaces are to reduce the cost of hardware, office space, business trips and more.

Undoubtedly, such changes require adaptation of the company's management system in order to maintain discipline and overall continuity of economic processes. Therefore, the need for systemic changes regarding digitization should be emphasized, because only in this case they will have a positive effect on the competitiveness of the company and will not lead to an imbalance of the organization.

The introduction of the concept of digital jobs provides:

- the transformation of jobs of public servants into digital jobs;

- preparing legislative initiatives to encourage the use of digital jobs by businesses and citizens[7].

Another significant aspect of the agrarian sphere digitization, mentioned in the Concept, is the Digital Agriculture unit, which describes the basic parameters of the introduction of information and analytical technologies in agricultural production and regulates the purpose of this process, which, in addition to its economic content, has a social aspectaswell.

Thus, a key goal of precision farming is to identify a healthy society that needs to consume healthy, agriculturalproducts, unsaturated chemicals and fertilizers. The bottom line is that the introduction of chemicals "on the eye" leads to an increase in the incidence of citizens, the spread of pathologies among the younger generation, reducing life expectancy through the glut of food harmful chemicals that enter the products at the stage of cultivation of crops. This, in turn, adversely affects the demographic situation, the economy of the country as a whole.

The use of precision farming technologies in combination with high-yielding black earths and domestic agrarian entrepreneurship should shape the high level of competitiveness of the Ukrainian agricultural sector on the world stage, especially in the organic production sector.

In addition to the high demand for this type of production, which determines its economic feasibility, with the use of precision farming technology, there is a possibility to reduce production costs by reducing the amount of mineral fertilizers and plant protection products (according to expert estimates by $30-50 \%$ ).

Preconditions for precision agriculture development in Ukraine: 
-presence in all natural areas of the country of spatial heterogeneity of soil cover: physical, physical-mechanical, chemical, agrochemical features;

-the rapid development of the agro-sphere in recent years, which means the presence of capital, business, market relations, which, together with various factors, already provides Ukraine with the first position in the world for certain types of products;

-successful commercial activities of numerous companies producing the necessary equipment, software, technologies;

- successful experience in developing the precision farming system in the enterprises [8].

\section{CONCLUSION}

Digitization of agricultural production is an objective requirement of time. By analogy with the logistical approach to management, which once became a breakthrough in the rationalization of production, in today's context, digitization is a source of generating competitive advantages and ensuring sustainable competitiveness of enterprises. From an economic point of view, it is a means of reducing the costs of organizing individual production and economic operations and optimizing the process of managerial decision-making.

From an environmental point of view, investing in digitization is also justified, since contributing to the reduction of agricultural chemistry while improving economic efficiency means limiting their migration beyond the topsoil, which reduces soil contamination, atmospheric, hydrofluid and biofilm.

From a social standpoint, the introduction of "digital" technologies will help to increase the attractiveness of working in the agro-sphere, translating field workers into offices, raising their level of economic culture and environmental awareness.

The main aspects that need to be addressed in order to digitize the agrarian sector are:

-providing support for the production, technical, educational and scientific aspects of digital technologies;

- training of qualified specialists, armed with the latest knowledge;

- creating an atmosphere of promoting the "digitalization" of the agricultural sector in the regulatory and political aspects.

\section{REFERENCES}

1. Rodionov D. Digitization in German or precision agriculture in $2019 . \quad$ Retrieved from: http://agro-business.com.ua/agro/mekhanizatsiia-apk/item/130 46-didzhytalizatsiia-ponimetsky-abo-

tochne-agriculture-in-frn.html.

2. Omelyanenko TV, Barabas DO, Vakulenko AV Management of enterprise competitiveness: A study-method. tool. for self. study - K .: KNEU, 2006. 272 p.

3. Hudzinskyi O., The Management System of Institutional Transformation of the Ukrainian Economy (Theoretical and Methodological Aspect) Kyiv, Agar Media Group , 2012, 771 p.

4. Klischuk L. Agrarian Business in the Digital Age - Ukrainian Realities, 2018. Retrieved from: https://nachasi.com/2018/10/02/it-zemlerobstvo/

5. Boyko Y. Digitization of the agrarian business: without "pink glasses", $2018 . \quad$ Retrieved from: http://agroportal.ua/en/views/blogs/didzhitalizatsiya-ukrainsko go-agrobiznesa-bez-rozovykh-ochkov/

6. On approval of the Concept of development of the digital economy and society of Ukraine for 2018-2020 and approval of the plan of measures for its implementation, 2018. Retrieved from: https://zakon.rada.gov.ua/laws/show/67-2018-\%D1 \% 80

7. Fischuk V. Digitization is just the beginning ", 2018. Retrieved from:

https://day.kyiv.ua/en/article/ekonomika/didzhytalizaciya-ce-1 yshe-pochatok

8. Digital Agenda of Ukraine, 2018. Retrieved from: 2020https: //ucci.org.ua/uploads/files/58e78ee3c3922.pdf

9. Michael Rachinger, Romana Rauter, Christiana Mbller, Wolfgang Vorraber, Eva Schirgi. Digitalization and its impact on business model innovation. Journal of Manufacturing Technology Management. 2018. Vol. 20. № 7. R. 95-124. DOI: 10.1108 / JMTM-01-2018-0020.

10. Schwab K. The Fourth Industrial Revolution: What It Means, How to Respond, 2016. Retrieved from:https://www.weforum.org/agenda/2016/01/the-fourth-in dustrial-revolution-what-itmeans- and-how-to-respond/.

11. Kharchenko V., Kharchenko H. Production resources use optimization at agricultural enterprises // Actual Problems in Economics; Kiev, Iss. 172, 2015, pp. 458-464.

\section{AUTHORS PROFILE}

Tatiana Ostapchuk, Doctor of economics, Assistant Professor, Head of the Department of Management and Entrepreneurship of Zhytomyr Polytechnic State University.

Scientific interests: accounting for investment activities, accounting in budgetary institutions, accounting for land relations, management, enterpreneurship.

The author of 75 publications, including 52 scientific and 23 educational and methodical works, including 12 co-authored monographs, 37 publications in professional journals, 28 co-authored textbooks and manuals. Is also a co-author of the textbook with the stamp of the Ministry of Education and Science of Ukraine "Accounting", as well as textbooks "Accounting and auditing in pharmacies", "Accounting in catering", "Economic analysis", "Accounting in construction", "Accounting in budgetary institutions. "

ORCID id: https://orcid.org/0000-0001-9623-0481

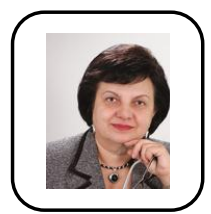

\section{Halyna Kupalova}

Doctor of Economic Sciences, Professor, Department of Environmental Management and Entrepreneurship, Taras Shevchenko National University of Kyiv.

Scientific interests: Problems of environmental economics, environmental management and entrepreneurship, trade, social policy, labor market, methodology of economic research

The number of articles in the national database -253 . The number of articles in international databases -30 .

Number ORCID:https://orcid.org/0000-0003-4486-8349

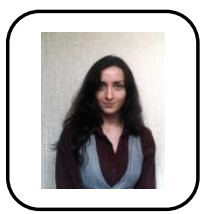

Y. Hudzynska, Department of management named after prof. Y. S. Zavadskyi, National University of Life AndEnvironmental Sciences of Ukraine. young scientist in management. Her scientific activity is aimed at developing theoretical, methodological and practical recommendations for managing the strategic development of enterprises and forming a system for ensuring their sustainable competitiveness in a highly competitive globalized market. 
The author of more than 30 scientific papers on management problems, in particular such articles: Methodological Aspects of Forming Mathematic Models of Management of Socio-economic Systems Development(2019); Transformations in Contemporary Society: Economic Aspects (2017); Peculiarities of Putting Strategic Goals and Priorities for Agricultural Enterprises in the Context of Economic Integration Processes (2014)

ORCID id: https://orcid.org/0000-0002-6850-4059

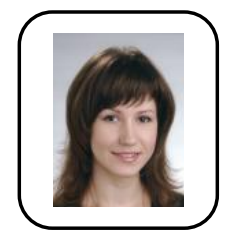

L.Butsenko, $\mathrm{PhD}$ in Economics, Associate Professor of the Department of management named after prof. Y. S. Zavadskyi, National university of Life and Environmental Sciences of Ukraineю

Young scientist in management. Her scientific competitiveness of enterprises of agricultural sector of economy. The author of over 30 scientific papers on management problems, in particular such articles: Methodological approach to the assessment of competitive advantages of agricultural enterprises (2012), Analysis of Competitiveness of Enterprises and concepts that define the degree of realization (2010)

ORCID id: https://orcid.org/0000-0002-6180-9618 